\title{
高分解能CTが診断と重症度判定に有用であった陰圧性肺水腫 の1例
}

\author{
矢野 隆郎*1 山内弘一郎*1 丸田 豊明*2 \\ 丸田望*2 窪田 悦二*2 甲斐 糸乃*3 \\ *1宮崎県立延岡病院救急 - 集中治療室, $* 2$ 同 麻酔科, $* 3$ 同 整形外科 \\ （ ( 882-0835 宮崎県延岡市新小路2-1-10）
}

Key words: (1) negative pressure pulmonary edema, (2) high resolution CT, (3) laryngospasm

\section{はじめに}

Laryngeal mask airway (LMA) 抜去時の喉頭痤攣が 原因と考えられる陰圧性肺水腫 (negative pressure pulmonary edema, NPPE)の症例を経験したので報告 する。

\section{症 例}

27 歳, 男性。身長 $179 \mathrm{~cm}$, 体重 $80 \mathrm{~kg}$ 。特記すべき 既往歴なし。

右肩鎖関節脱臼の観血的整復術に対し，LMAを用い た吸入麻酔を施行した。外傷性くも膜下出血を合併し ていたが, 受傷後 1 週間以上経過しており, 神経学的異 常はなく, 頭部 CT上の出血病変も消失していた。麻酔 導入時, 用手的気道確保及びマスク換気は容易で, LMA (ソフトシールTM, Size 4, Smiths Medical, USA) を盲目的にスムーズに挿入できた。麻酔中は, 呼気の 漏れもなく自発呼吸下で維持した。術中バイタルサイ ンは安定して経過した。手術は, 所用時間 1 時間 20 分, 輸液総量 $1,200 \mathrm{~m} l$ で終了した。

終了約 10 分後から不穏となり, LMA を誤咬しそうに なったため, 不十分な覚醒でLMAを抜去し, マスクに て酸素 $6 \mathrm{l} / \mathrm{min}$ を投与した。この直後に強い吸気性喘鳴 と鎖骨上窩の陥没呼吸が出現したため, 上気道閉塞状 態と判断した。この時, モニター上 $\mathrm{SpO}_{2}$ は $96 \%$ であっ た。下顛挙上法にて気道確保し, 右鼻孔より鼻咽頭エ アウェイ (内径 $8 \mathrm{~mm}$ )を挿入したが, 改善しなかった。 経鼻的に口腔，咽頭部を吸引したが，分泌物，血液，異 物は吸引できなかった。 $\mathrm{SpO}_{2}$ が $85 \%$ に低下しため, 準
備でき次第気管挿管するつもりで, 100\%酸素で用手的 陽圧換気 (30 $\mathrm{cm} \mathrm{H}_{2} \mathrm{O}$ 程度) を開始した。徐々にカプノ グラムが出現し， $\mathrm{SpO}_{2}$ は $90 \%$ 以上に上昇し続けた。陽 圧換気を続けたところ, 前胸壁の挙上も認められるよ うになり, $\mathrm{SpO}_{2} 93 \%$ の時点で動脈血ガス所見は $\mathrm{pH}$ 7.38, $\mathrm{PaCO}_{2} 40.6$ mmHg, $\mathrm{PaO}_{2} 73.4 \mathrm{mmHg}, \mathrm{BE}-4.0$ であった。LMA抜去約 5 分後には $\mathrm{SpO}_{2}$ が $95 \%$ に改善 したため，気管挿管は施行しなかった。LMA抜去 10 分 後には意識清明となり, 気道確保及び陽圧換気を中止 し，鼻咽頭エアウェイを抜去しても吸気性喘鳴と陷没 呼吸は出現しなかった。呼吸困難や咳, 喀痰はなかっ たが, 酸素 $6 \mathrm{l} / \mathrm{min}$ 投与下で $\mathrm{SpO}_{2} 95 \%$ のままであった。 LMA 抜去 30 分後の胸部X 線写真 (Fig. 1a) で右肺野を 中心とした浸潤影を認め, LMA抜去 1 時間後の胸部高 分解能 CT (high resolution CT, HRCT) (Fig. 1b) で両 側肺野, 特に右上肺野に間質性陰影の増強のみを認め, 急性間質性肺水腫と診断した。吸引性肺炎及び無気肺 は否定的であり，治療は持続陽圧換気や利尿薬を使用 することなく，酸素投与のみを行った。

翌日には胸部X線写真の異常浸潤影は消失し, $\mathrm{SpO}_{2}$ は大気下で $99 \%$ に改善した。Pro brain natriuretic peptide (BNP) は $19 \mathrm{pg} / \mathrm{m} l$ と正常值で心不全は否定的 であった。後日，抜釘目的にて気管抻管による全身麻 酔を施行した際, 口腔, 咽頭, 喉頭には, 解剖学的異常 を認めなかった。

\section{考 察}

急性上気道閉塞による過大な胸腔内陰圧が, 肺毛細 血管透過性の㠵進と肺毛細血管血液量の増加を生じ,

A case of negative pressure pulmonary edema that the findings of high resolution CT were useful for the diagnosis and severity judgment

Takao Yano*1, Koichiro Yamauchi*1, Toyoaki Maruta*2, Nozomi Maruta*2, Etsuji Kubota*2, Itono Kai*3

${ }^{* 1}$ Emergency Center and Intensive Care Unit, *2 Department of Anesthesia, *3 Department of Orthopaedics, Miyazaki Prefectural Nobeoka Hospital (2-1-10 Shinkouji, Nobeoka, Miyazaki 882-0835, Japan) 
(a)

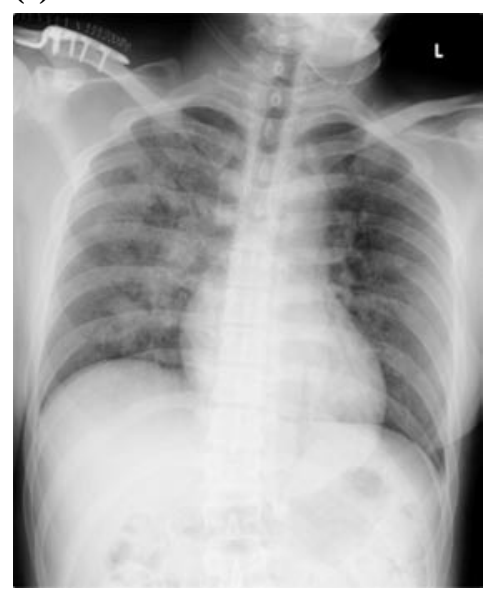

(b)

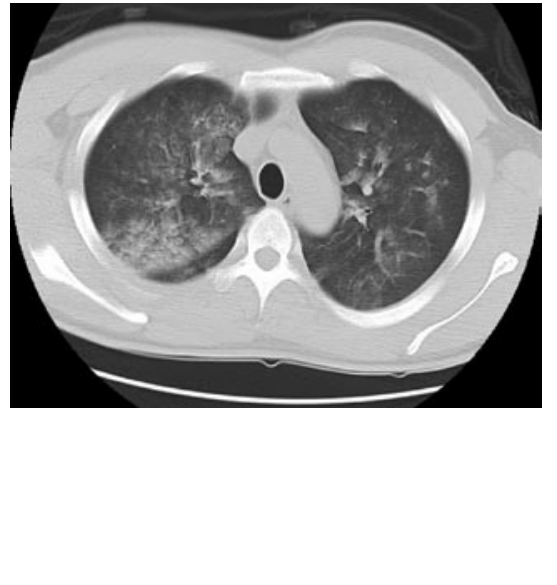

Fig. 1 The chest radiograph and HRCT

(a) Chest radiograph shows bilateral infiltration mainly in the right lung field without enlargement of the heart and the vascular pedicle.

(b) Chest HRCT reveals bilateral interstitial pattern infiltration such as ground-glass opacity, interlobular septal thickening and peribronchial cuffing with centrilobular density mainly in the right upper lung field.

HRCT, high resolution CT.
NPPEを起こすと推定されている。このような急性上 気道閉塞の原因として, 抜管後の喉頭痤攣 1 , 麻酔終了 時LMAの位置のずれによる喉頭閉塞 ${ }^{2}$, LMA抜去後 の喉頭痤攣 3 ) 等の報告がある。本症例は, 臨床経過及び 挿管麻酔時の解剖学的所見から, LMA抜去後の喉頭痤 攣が原因であった可能性が高い。

胸部 X 線写真や従来の CT 検査に比べ, 胸部 HRCTは 肺胞間質陰影の解剖学的構造や分布を明瞭に描出でき る。ヘリカルスキャンにより高速・高分解能化し, 0.5 $\mathrm{mm}$ の収集で全肺野が一呼吸で収集可能となり, 酸素 投与が必要な呼吸窮迫のある患者においても撮影が可 能である。NPPEのHRCT所見は, 中心性肺間質性陰 影が, 上葉を中心に背側以外にも分布するのが特徵 で4),5), 他に術直後の呼吸不全の原因となる心不全 (末 梢血管陰影増強, 胸水, 末梢性間質性陰影), 誤嚥性肺 炎 (下葉, 背部の肺胞性陰影) とは異なる。したがって, HRCTの所見はNPPEの確定及び鑑別診断に有用であ る。

NPPEには軽症型の間質性肺水腫と重症型の肺胞性 肺水腫がある6)。軽症の NPPEは, 低酸素血症, 頻呼吸, ラ音聴取等で気づかれるが, 利尿薬や人工呼吸等の特 別な治療を必要とせず, 酸素投与のみで改善する11。 軽症例は, 喀痰を伴うことが殆ど無く, 間質性肺水腫が 主体である可能性が高い4)。一方, 重症のNPPEは気 管粘膜血管床や肺胞毛細血管膜の破壊を合併し, ピン ク色の泡沫様喀痰を吸引できる肺胞性肺水腫を呈する。 一回換気量及び肺コンプライアンスの低下が前者より 進行し, 発症直後から人工呼吸管理を要する症例5),7),8) や, 経過中に重症化しcontinuous positive airway pressure (CPAP) 等の治療を要する症例がある9)。 HRCTは軽症型と重症型の鑑別も可能であり，前者は 間質陰影のみを認めるが, 後者では間質の増強に加え, 肺胞内浸潤陰影を上葉中心に背側以外にも認め る5),8),9)。

本症例は, 胸部 HRCT 検査にて間質の増強のみを認 めたため, 軽症型の間質性肺水腫の NPPEと判断し, 酸 素投与のみで経過観察して発症 24 時間以内に改善し
た。

本症例の反省点として, LMA抜去の不適切なタイミ ングや胃酸逆流により, 喉頭痤攣を起こした可能性が 考えられた10)。喉頭病攣予防目的にて, LMAの深麻酔 下抜去, 胃酸逆流予防対策を行い, 更に喉頭痤攣時には, より迅速な気管挿管を考慮すべきであった。

\section{結 語}

確定及び鑑別診断と重症度判定にHRCTが有用で あったNPPEの1症例を報告した。

\section{文 献}

1) Willms D, Shure D. Pulmonary edema due to upper airway obstruction in adults. Chest 1988;94:1090-2.

2) Buttiglieri A, Di Ciero G, Verdecchia C, et al. Acute pulmonary edema from dislocation of a laryngeal mask. Minerva Anestesiol 1999;65:675-8.

3) Sickmann K, Seider R, Dahm M, et al. Negative pressure pulmonary edema. Post-obstructive lung edema after use of a laryngeal mask. Anaesthesist 2005;54:1197-200.

4) Maniwa K, Tanaka E, Inoue T, et al. Interstitial pulmonary edema revealed by high-resolution CT after relief of acute upper airway obstruction. Radiat Med 2005;23:139-41.

5) Broccard AF, Liaudet L, Aubert JD, et al. Negative pressure post-tracheal extubation alveolar hemorrhage. Anesth Analg 2001:92:273-5

6) 崎尾秀彰．陰圧性肺水腫を見逃すな．日集中医誌 2008:15: 276-8.

7) Marchertiene IA, Macas A, Karbonskiene A. Pulmonary edema and hemorrhage as complications of acute airway obstruction following anesthesia. Medicina (Kaunas) 2008:44:871-6.

8) Papaioannou V, Terzi I, Dragoumanis C, et al. Negativepressure acute tracheobronchial hemorrhage and pulmonary edema. J Anesth 2009;23:417-20.

9) Brandt L, Mielke A, Hackländer T. Negative-pressure pulmonary edema after general anaesthesia. Imaging diagnostic procedure. Anaesthesist 2008;57:359-63.

10) Gataure PS, Latto IP, Rust S. Complications associated with removal of the laryngeal mask airway: a comparison of removal in deeply anaesthetized versus awake patients. Can J Anaesth 1995;42:1113-6. 採択日 2010 年 8 月 16 日 